\title{
Who was the translator of the anonymous 1821 of Goethe's \\ Faustus? Could the translator have been Coleridge?
}

\author{
Refat Aljumily
}

\begin{abstract}
The 1821 translation of Goethe's Faustus is not signed by the translator. We know who translated Friedrich Schiller'shistorical dramas ThePiccolominiand The Death of Wallenstein, for example, not because the translator identified himself as Coleridge but based on evidence from within and without. This article offers a three-part review to 'Faustus' from the German of Goethe translated by Samuel Taylor Coleridge' (Oxford University Press, 2007), edited by Frederick Burwick and James C. McKusick. It argues that there is no definitive evidence during Coleridge's lifetime or for centuries after his death that Coleridge was acting as an anonymous translator of Bossey's text as Faustus.
\end{abstract}

\section{Keywords}

Faustus, Coleridge, Boosey and Sons, documentary evidence, internal evidence, external evidence, Stylometry 


\title{
Who was the translator of the anonymous 1821 of Goethe's Faustus? Could the translator have been Coleridge?
}

\author{
Refat Aljumily
}

Nearly fourteen years after the publication of Faustus: from the German of Goethe translated by Samuel Taylor Coleridge' (Oxford University Press, 2007) edited by Professors Frederick Burwick and James C. McKusick and revealed Coleridge as the translator of Faustus text ${ }^{1}$, but at Coleridge's insistence, it was published anonymously in $1821^{2}$. It's refreshing to write down some of my thoughts about it that didn't necessarily cohere practically elsewhere ${ }^{3}$.

And while the claim that the translation of Faustus text comes from Coleridge's hand is controversial today, historically it hasn't been ${ }^{4}$. And it's exactly the position I adopted here or in 2015 when I completed my topic of research. Now I plan to return to this topic to review the documentary, linguistic, and stylometric evidence with more depth. In this review, I hope to contribute further to this argument by providing documentary evidence from the period between August 1819 to February 1822 when Coleridge lived at Highgate and by evaluating the linguistic and stylometric pieces of evidence in the light of more recently available evidence.

${ }^{1}$ Part I of Faust, which appeared in 1808, is one of the most celebrated works of Johann Wolfgang von Goethe, and is considered a masterpiece of nineteenth-century literature. Six incomplete English translations of Faust appeared not long after its publication, one of which is the verse translation published anonymously by Thomas Boosey in 1821 .

${ }^{2}$ Burwickand Mckusick(2007: xxiv).

${ }^{3}$ Refat Aljumily (2015). The Anonymous 1821 Translation of Goethe's Faustus: A Cluster Analysis Approach. Newcastle University, https://core.ac.uk/download/pdf/15377990.

${ }^{4}$ The claim that Coleridge translated Faustus was first investigated by William A. Speck (died 1928). The claim then investigated by Carl F. Schreiber in 1947 who found no known connection between Coleridge and the 1821 translation based on discovery of exchange of letters between Booseys and Coleridge which settled the matter, and others have agreed. See Paulin, R., Clair, W., and Shaffer, E. 2008. 'A Gentleman of Literary Eminence'.Available from: http://sas-space.sas.ac.uk/4530/1/stc-faustusreview. pdf and Mays, J.C.C. (2012:123), ' Faustus on the table at Highgate'. The Wordsworth Circle 43(3), 119-119. 
In this Oxford edition, Professor Burwick looked for both external and internal evidence (pp: xx-liv) to link Coleridge with Goethe's text, while Professor McKusick looked for internal evidence using textual statistical measure (Stylometry) (pp:311-30) to establish Coleridge's authorship by comparing the 1821 anonymous translation ${ }^{5}$ to Coleridge works, as well as writings of other contenders from that period, such as Germaine de Staël ${ }^{6}$, George Soane ${ }^{7}$, Daniel Boileau ${ }^{8}$, John Anster ${ }^{9}$ and Lord Francis Leveson-Gower ${ }^{10}$. I will address each piece of evidence in turn. Let's start with the letters and other documentary materials.

As is clear from the rather lengthy introduction in the volume, the main focus of it is on the so-called "the textual and documentary evidence of Coleridge's authorship". In the matter of the documentary evidence, there are two parts of it that I found interesting. In the first part, at most three letters are in play, all requiring argument: the first letter is from Coleridge sent to the publisher Boosey in 1820 in reply to some kind of offer or request from Boosey regarding suitable dramatic and poetical translation strategy for his second edition with a draft of Boosey's reply and Coleridge's 'My Advice and Scheme' two days later of how best to set about it, the second is from the publisher Bohte sent to Goethe in 1820, and the third letter from Goethe sent to his son August in 1820.

I would certainly agree the letters provide us with a fairly good idea of literary transactions from the publishers of English translations of German's literature particularly John Murray, Thomas Boosey, and Johann Heinrich Bohte who decided to publish the first part of Goethe's Faustus and entered into negotiation with Coleridge or tried to induce him to make extracts from it available to English readers. According to the first letter and accompanying closures, one can confirm that Coleridge had once intended to translate the play for the publisher John Murray in 1814 but Coleridge never translated it for him. The rival publisher Boosey planned another publication, with additional scenes from Faustus, to go with the second edition of Moritz Retzsch illustrations. He approached Coleridge with an offer, but it cannot be ascertained whether a translation of Faustus was undertaken. Instead, Coleridge offered advice on the translation that would accompany the text to the publisher Boosey in 1820. Coleridge

${ }^{5}$ Faustus: from the German of Goethe. London: Boosey and Sons, 1821. (this is called Coleridge's translation in the edition that illustrated with 27 line engravings copied by Henry Moses after the original plates by Mortiz Retzsch).

${ }^{6}$ Germaine de Staël, Germany [= de l'Allemagne, 1809], edited by William Lamb (London: John Murray, 1813). Part II 'On Literature and the Arts', Ch. 23, 'Faustus', pp. 181-226.

${ }^{7}$ Extracts from Göthe's Tragedy of Faustus, explanatory of the plates by Retsch, translated by George Soane (London: Bohte, 1820). [January 1820] Page proofs for Bohte's planned second edition, translated by George Soane. [Sent to London Magazine, Nov 1821; to Goethe June 1822]

${ }^{8}$ Retsch's Series of Twenty-six Outlines Illustrative of Goethe's Tragedy of Faust, translated by Daniel Boileau (London: Boosey, 1820). [June 1820], with Boileau's notes to Abraham Hayward's prose translation.

9 'The Faustus of Goethe', translated by John Anster, Blackwood's Edinburgh Magazine, vol. 7. no. 39 (June 1820), 235-258.

${ }^{10}$ Faust: a Drama by Goethe; and, Schiller's Song of the Bell, translated by Lord Francis Leveson Gower. (London: John Murray, 1823). 
suggested that a blank verse drama mixed with prose summaries would be the best way to translate and represent Goethe's text. According to the second letter or Bohte's letter, which was sent on 1 August 1820 to Goethe to tell him that Coleridge was working on his Faustus for Boosey, “... and I have learned to my pleasure that the poet Coleridge here is working on a complete translation of this dramatic poem...", one can confirm that it gives no definite evidence that Coleridge was actually translating the play or he has agreed to undertake a translation or even that Coleridge's translating job is underway. Here the phrase "I have learned that the poet Coleridge..." suggests that Goethe's Faustus was a subject for a third party gossip or a literary gossip that helped Goethe or the publisher Bohte to sell the translation based on a scandalous connection to one already famous literary figure like Coleridge. Probably the most controversial letter in the documentary evidence is Goethe's letter, which was sent on $4^{\text {th }}$ September 1820 to his son August. This letter (if it were true) dictated the publisher Bohte's news that Coleridge was translating Faustus. There can be a doubt that this letter is true because Bohte was certainly wrong about "a complete translation" simply because there is no evidence of Coleridge agreeing to make a complete or partial translation for Murray in 1814 or Boosey in 1820/21. Arguably and most importantly, there is nothing on the historical record that shows Bohte privately or publicly concluded anything about Coleridge's involvement in the Boosey translation during the last five years of his life. Goethe is likely to have misunderstood Bohte that Coleridge was working on his Faustus.

The second part of the documentary evidence is the wider reception of a translation of Goethe's Faustus. In broad terms, there are pointers or references made by Coleridge's contemporaries and subsequent generations who alluded to the possibility of Coleridge might have translated Faustus, which seem to me to be fairly indirect evidence. The first allusion comes from Goethe when he appreciatively quoted lines of Coleridge's poem "To William Wordsworth" in a conversation with Friedrich Frster (September 27, 1820, i.e. less than two months after Goethe being informed that Coleridge was at work on Faustus) in which Frster records: "He was always of the opinion that the indicated passages had no need of musical support, wherein he completely agreed with the keen-witted Coleridge". The second comes from William Barnard Clarke's translation of Faustus parts I and II in 1865 when he refers to Coleridge as the translator saying that an earlier translation "said to be by Coleridge" ( $\mathrm{p}$ : liv). The third comes from William Hauhart ${ }^{11}$ who shows little doubt that Coleridge's translation might be among the other translations that failed to come to light. And the fourth and the last allusion comes from Rosemary D. Ashton ${ }^{12}$ who states that almost everything indicates the possibility of Coleridge's missing translation; she concludes that Faustus was to be one of the many of Coleridgean projects that "never got off the ground". In my evaluation, these allusions or references in no way prove Coleridge translated Goethe's text as Faustus. Maybe these references or statements are enough to

\footnotetext{
${ }^{11}$ Hauhart, W. F. 1909. The Reception of Goethe's Faust in England. New York: The Colombia University Press. $(32,95)$

${ }^{12}$ Ashton, R. D. 1977. 'Coleridge and Faust'.Review of English Studies 28: 156-167.
} 
tell us that Coleridge seems a reasonable candidate on account of his competence in the German language and his interest in German literature. We know from the literature that Coleridge studied the German language and acquired considerable knowledge of German literature before his departure to Germany in 1798. He wrote a small number of original poems in German and translated some other long poems into German. We also know that Coleridge translated Schiller's Piccolomini and The Death of Wallenstein into English, a translation that even his contemporaries had appreciated. For example, Shelley P. B. is reported to have said that "no one but Coleridge is capable of this work" 13 and Henry Crabb Robinson is reported to have said that “...there is no doubt that Coleridge's mind is much more German than English... he is eminently qualified to bring the literature of Germany to the attention of his countrymen" 14 .

It appears that Professor Burwick perhaps ignored or possibly misread the available historical documentary evidence ${ }^{15}$ which gives the possibility of another translator more legitimacy. The reason I ultimately come back to when evaluating Professor Burwick's documentary evidence is that in various interviews Coleridge said he didn't translate Faustus. As he put it in the "Table Talk" of February 16, 1833, "I need to tell you, I never put pen to paper as a translator of Faust" ${ }^{16}$ or as he put it in the conversation with Giaocchino de' Prati of May 1825, "I would have attempted to translate your favorite 'Faustus', but I must give it up in despair. To translate it to make the English readers acquainted with the plot, is a foolish task...”, I would argue that Coleridgedidn't translate this Faustus. That's what is so unconvincing about Professor Burwick's documentary evidence. Professor Burwick skates over Coleridge's assertion as if it did not exist. Although he doesn't say that Coleridge was lying, he implies that he was ${ }^{17}$. Professor Burwick speculates that Coleridge was very careful to avoid revealing in public or with friends his admiration for the text of Goethe and he translated it secretly (Intellectual dishonesty, isn't it?), and Boosey upheld Coleridge's anonymity. But that dishonesty must have a motive behind it. Well, according to Professor Burwick(xxiv) there are at least four reasons to believe Coleridge hid the truth in his "Table Talk" assertion: (i) Coleridge unfulfilled previous commitment to the publisher John Murray and his fear that Murray would pursue him for the $£ 100$ he owed, and (ii) to take another advance from Boosey, (iii)the text contained themes of seduction, murder, and questionings of religion that made Coleridge uncomfortable, and (iv) Coleridge didn't want to show he had difficulty carrying it through to completion. But even if we assume that Coleridge translated Faustus secretly to Boosey and then pretended he hadn't done

\footnotetext{
${ }^{13}$ Mays, J.C.C. (2012:123). 'Faustus on the table at Highgate'.The Wordsworth Circle 43(3), 119-127.

${ }^{14}$ Hauhart, op.cit., 63

${ }^{15}$ There are large documents (collection of Goethiana which is available from Yale University Library) relating to Goethe (i.e. letters between Booseys and Coleridge and between Bohte and Goethe in full). Paulin, R., Clair, W., and Shaffer, E., op.cit., 7

${ }^{16}$ Coleridge.Table Talk, 1833, vol. II, p.117

${ }^{17}$ Coleridge did "not only put pen to paper", but "had done so with ardour and determination". (Burwick and McKusick, 2007: xxx). In a separate statement, Professor Mckusick claims that Coleridge "Lied...he was covering his own tail. Otherwise, Murray will come after me for his 100 pounds, plus interest, plus breach of contract."
} 
so, what is there to prove that Coleridge wasn't aware of his literary persona? ${ }^{18} \mathrm{Of}$ course, one can speculate, but we won't know for sure. Taking Coleridge's life course (Coleridge's financial problems and his publishing history and dealings with publishers) and making the case that Faustus is a work by Coleridge is the extremely improbable conclusion $^{19}$, and I see no reason to assume that Coleridge told a fib or hid the truth when other explanations are far more plausible ${ }^{20}$. First, where is the evidence that Coleridge gave a false statement in the "Table Talk" that he was not the translator, and did so with the intention to deceive the public or the literary world for the reasons or motive stated above? The terms of Coleridge's unfulfilled commitment with Murray in 1814 were clear that the $£ 100$ payment would come only after the completion of the translation ${ }^{21}$, and that Coleridge's continued connection with Murray suggests there was no animosity between them, and no attempt by Coleridge to avoid the publisher, Murray. This can be referred to on several occasions throughout the period from 1812 up to 1825 . For example, when Murray went on to publish 'Christabel' for Coleridge in 1816, or when Coleridge wrote a letter of introduction to Murray for Mariana Starke in 1819 to submit to him a travel book she had written and Murray published it in 1820 as 'Travels on the Continent', or when Coleridge recommended in 1820 Hurwitz's Vindiciae Hebraicae to Murray for publication, or when Coleridge wrote a letter to Murray in 18 Jan1822 offering him a volume of 'The Beauties of Archbishop Leighton Selected Methodized, with a (better) Life of the Author' and Murray asked Coleridge to review it.

Second, where is the evidence that Coleridge had second thoughts and decided to re-translate the play after having refused to undertake it in 1814?. We know from the literature that Coleridge had second thoughts about Goethe that he rated him below Schiller after he had read the earlier edition of Faustus, but when Henry Crabb Robinson read to Coleridge several scenes out of the new 'Faust', Coleridge acknowledged the genius of Goethe as he had never before acknowledged $i^{22}$. We also know from the literature that Coleridge had never had second thoughts about the immoral and atheistic themes of the play. The offer to Coleridge that he should undertake to translate Faustus never received serious attention from him in two ways, first by expressing his objections mainly on the basis that the language of the Prologue or the beginning of Faustus was "blasphemous." Secondly, by giving reasons for his moral misgivings; Coleridge's mind misgave him that his moral character might suffer by translating Faustus and that the translation would offend the English people. In addition to these moral misgivings,

\footnotetext{
${ }^{18}$ I personally feel that Coleridge was aware that anonymous production of the play could easily be employed to damage his reputation, impugn his morality or compromise his social standing.

${ }^{19}$ We know that Coleridge published materials anonymously in the 1790 s in which he or publishers made open secrets of their anonymity. We also know that Coleridge imitated poems and assisted friends in a contribution for a literary society, but logically we can't make the case for Coleridge authorship from his past actions, behavior, and situations.

${ }^{20}$ When Coleridge denied or concealed authorship, how do we know if he spoke the truth or not, since none among men knows what goes on within a man but the spirit of a man which is in him. So I will use my logic and voice my critical review on five pieces of evidence to arrive at my own conclusion.

${ }^{21}$ See the broken agreements with Murray and Longmans in Paulin, R., Clair, W., and Shaffer, E., op. cit., 1314

${ }^{22}$ Hauhart, op. cit., 64
} 
Coleridge had respect for Charles Lamb's judgment ${ }^{23}$ who advised him not to translate Faustus which acted as a deterrent upon $\operatorname{him}^{24}$. It is hard to imagine that Coleridge who gave his critical opinion of Faustus in various interviews would change his mind and decide to translate it. Coleridge's criticism made during his lifetime to the play didn't evolve over time. In each interview, Coleridge's critical opinion came back very clear and very unambiguous. Coleridge initially said that "the want of religion and enthusiasm in Goethe is an irreparable defect". Later, when he continued his criticism and expressed the same opinion in the "Table Talk", Coleridge called Faustus a "ready-made conjurer from the beginning." Coleridge also criticized the loose dramatic structure of Faustus, and the change in the character of Goethe's hero, or as Coleridge expressed it, "that the sensuality and the thirst for knowledge are not connected with each other." On that basis, if Coleridge was the translator of Faustus, he probably would not have said: "There is no whole in the poem.", and there is nothing on record to show Coleridge opinion of the completed Faustus. Coleridge even did not look forward to the publication of the Second Part of it.

Third, where is the evidence that Coleridge was working on Faustus secretly? This can be determined by the place Coleridge lives in. Coleridge spent most of the remainder of his life (i.e. from 1816 to 1834) in the household of Dr. and MrsGillmans at Highgate with only brief periods away. During these years, Coleridge virtually became a member of the Gillman family and even accompanied them on annual vacation. If Coleridge had chosen to want to lie he would never have concealed it from the Gillmans at all. The Gillmans had acted not 'merely as Coleridge's hosts but as his closest companions, friends, confidants, and staunch admirers who became increasingly aware of Coleridge's personal life, private difficulties, and professional career and even Gillman was sometimes acting on Coleridge's behalf in London. The Gillmans provided Coleridge with constant support, sympathetic care, and an environment in which he could work, and be happy. The point is that the documentary record from that period (between 1819 and 1822) which is relevant to the questioning of Professor Burwick's documentary evidence shows that Coleridge was writing occasional poetry such as The Tears of a Grateful People on the day of the funeral of King George III which was published on 29 January 1820 while preparing literary and religious lectures, revising manuscripts such as Hyman Hurwitz's Vindiciae Hebraicae (published in 1820), working with his son Hartley on an essay on Metre illustrated and exemplified from Mr. Frere's Aristophanic poems which he offered to the Quarterly Review as a review of

${ }^{23}$ Charles Lamb and Coleridge were examples of true friends. They had strong and mutual respect for each other's minds that led each to want the other's opinion on what he read and thought and wrote. Coleridge died on July 251834 and Lamb died on December 271834 to whom it can be said that "in their deaths they were not divided”' Edith Christina Johnson. 'Lamb and Coleridge'. The American Scholar.Vol., 6, No. 2, 1937.

${ }^{24}$ When Lamb heard, in the summer of 1814, that his old friend Samuel Taylor Coleridge had been asked to translate Faust into English, he could hardly contain his horror and wrote to Coleridge on August 23: "I counsel thee", " "to let it alone ... how canst thou translate the language of cat-monkeys? Fie on such fantasies!" 
Frere's translations of Aristophanes (published in June or May 1820), and continuing to work with Joseph Henry Green, mainly on the Bible (perhaps sometime in 1822). So, on this basis if Coleridge was the translator, then, he would have left behind some recorded evidence (such as working drafts, letters, notes, annotations, marks, etc) or the Gillmans or anyone who called at Highate, I suppose he/she would have noticed Coleridge might have repeated certain behaviors or might have changed his daily activities (for example, busy in his study room working hard on the translation) in ways which would be, perhaps, similar to those experienced in 1800 with the translation of Schiller's The Piccolomini and The Death of Wallenstein ${ }^{25}$, with which to support one simple conclusion: Coleridge was the translator. But a major problem is that Coleridge never even hints publicly or secretly, in person or writing, during his lifetime that he may have translated any parts or fragments of Faustus. Even his eldest son Hartley, friends, publishers, and enemies never give any hint that he may have been involved in its production, both at the time and later. Instead, the recorded evidence shows that on 9 April 1820 Charles Mathew invited Coleridge to meet Sir Walter Scott in which he refused the meeting and declined an offer of an engagement from the publishers Boosey and Sons to write a commentary for an edition of Moritz Retzsch's illustrations of Goethe's Faustus. Coleridge came to feel that the task was beneath him, in which he said: "This, any man of common sense can do as well as I" 26.

Fourth, on two occasions Coleridge offered his technical advice on how Faustus should be translated, first when he wrote to the publisher Murray in 1814 insisting that much of Faustus should not be translated into blank verse but "must be in wild lyrical metres". Secondly, in 'My Advice and Scheme', dated 12 May 1820, when he said that selected passages should be translated "in the manner \& meter of the original". Since it is clear that whoever translated Faustus did not seem to take Coleridge's advice, unless it is translated in a blank verse drama mixed with prose summaries, Coleridge's engagement is significantly diminished. Apart from songs and choruses, the translation of Goethe's Faustus is all translated in blank verse.

Fifth, when assuming Coleridge as a translator of Faustus, I try to judge this translation by comparing how successfully he could have achieved with what he had achieved. That means the 1821 English translation of Goethe's Faustus was technically ranked lower than the translation of Schiller's The Piccolomini and The Death of Wallenstein. In addition to the issue of lexical borrowing I spotted (See note 34 below), the point is that the Faustus translation itself is a very strange translation since it "wouldn't have required both a first-rate translator and a first-rate poet to produce this Faustus" simply because it is "just not of the same order as the Wallenstein translations

${ }^{25}$ Coleridge complained to Thomas Poole of working 14 hours every day and informed Godwin that the effort had wasted and depressed his sprits and left a sense of weraness and disgust. Also, Coleridge expressed a sense of being conned in declaring to Samuel Purkis that he would not undertake another such translation 'never, never, never will I be so taken in again'.

${ }^{26}$ Michael Kellaway. Samuel Taylor Coleridge: the Highgate Years 1816-1834. (1974: 96-97). University of Edinburgh 
in terms of its ambition and its technical brilliance" 27 . Still, some may wonder how Coleridge - the able translator of Schiller's two plays, which both contain several thousand lines-produced a translation that lacks character and contains such simple errors. $^{28}$

By and large, neither of the documentary evidence provides enough proof to support the case for Coleridge one way or the other beyond the evidenced statement that Coleridge had never translated this Faustus. Coleridge's statement was not only categorical but also was as final as it could be to the rival publishers, literary friends, and competitors or enemies.

With regard to the internal evidence ${ }^{29}$, it consists of words and phrases that occurred in both the 1821 anonymous translation and Coleridge's works or what Professor Burwick describes as "Coleridgean verbal echoes and parallels in Boosey's 1821 edition". Words like "ramparted", "the forms of" "30, "silent thought", "soul's wild", "heart's wild", "bright hopes", “enlight'ning dull”, "no sweet imagining”, "to nature", "beam on my darkling spirit", "darkling", "moonshine", "witchery", "trembling hand", "sublime", "silly", and "bright sun". In a question like this, I would respectfully argue that such similarities between words and phrases in the Faustus translation and Coleridge's works are flawed attribution arguments. I will provide two reasons to explain this. Firstly, it is always possible to find similarities of images, ideas, words, and phrases between any two Romantic era-authors not because they are unique to either author, but simply because they are the norm, or even clichés, of the time. It is also possible that an author could use and imitate style markers of another author or work consciously or unconsciously, deliberately or otherwise. To use verbal echoes and parallels in attributing authorship correctly and demonstrably so, one needs first to define the norm of Coleridge's own time then to assess the value of their occurrence against that norm. In other words, what we needed from Professor Burwick was to see how often/how frequently these words or phrases were used by Coleridge and other writers of the period to make sure that a proposed verbal parallel or echo could be both unique and idiosyncratic. However, I put this reason to the test-did Romantic period writers in Coleridge's lifetime ever use any of these words or phrases in their published works? My investigation shows that there are many Romantic-era authors used the same words and phrases, among these are for example:

\footnotetext{
${ }^{27}$ Jennifer Howard.(2008). 'A Question of Evidence, or a Leap of Faith?'The Chronicle of Higher Education.

${ }^{28}$ Mays (2012: 119): Mays says it lacks character and contains such simple errors.

${ }^{29}$ Burwick and McKusick, op. cit., :xiiii -xliv-xxxvi.

${ }^{30}$ Professor Burwick states that in the translation the phrase "the forms of ages past" parallels to "the forms of other days" and "the forms of Memory" from Coleridge's 'Anna and Harland' (1790)(Burwick and McKusick, op. cit., : xxxviii) My investigation on the content of this poem in the original source text of Coleridge's poetical works (e.g. Mays, 2001, part I: 27; Coleridge, 1912: 17), shows that Professor Burwick makes a mistake with the parallel cited in Coleridge's 'Anna and Harland'. The mistake is evident as the line in this poem says: "The tales of other days before me glide:..." not "the forms of other days...".
} 
International Journal of English and Comparative Literary Studies, vol.2, no.2 (2021)

“Absorb'd in silent thought", Robert Southey, "Rudiger, Aballad", (1796)

"...the ramparts present many agreeable views of the river...", "William Wordsworth to Thomas Poole", (1798)

“A rampart wall was round her", Charlotte Elizabeth, "Derry, The Maiden City", (1833)

"Passion's wild career", Christopher Anstey, "Winter Amusement, An Ode" (1778)

"The bridegroom's wild despair", Bernard Barton, "Jane Ashford. A tale in Humble Life" (1778)

“Love's wild fever”, Barry Cornwall, "Diege de Montilla. A Spanish Tale" (1820)

"Grief's wild billows", Charles LIoyd, “Oswald, A Poem”, (1795)

"Ambition's wild career", Henry Boyd, "On the Death of the Rev. Thomas Stewart" (1798)

“Joy's wild throb”, Francis Wrangham, “The Raising of Jairus' Daughter, a Poem” (1803)

“The bright sun was extinguish'd and the stars...Did wander darkling in the eternal space...

..And flap their useless wings; the wildest brutes...", George G. Byron, “Darkness" (1816)

"While pityless the tempest wild", Robert Burns, "A Winter Night" (1786)

"Darkling I listen; and, for many a time", John Keats, "Ode a Nightingale" (1819)

"The hare limp'd trembling...Its little smoke, in pallid moonshine, died....Soon,

trembling in her soft and chilly nest", John Keats, "The Eve of St. Agnes" (1819)

"The bony forms of beast and man", Leveson-Gower, "(trans.) Faust: A Drama By

Goethe", lines 416, (1823)

Secondly, evidence from the literature shows that romantic-period authors are engaged with issues of literary borrowing and there are allegations or debate that the Romantic poets were plagiarists ${ }^{31}$. For example, Coleridge, Southey, and Wordsworth borrowed from each other's writing and used them in their works in the 1790s, Keats and Cornwall borrowed freely from each other when each wrote his sonnet 'Bright Star' in 1819 or1820, Shelley's 1816 poem 'Mont Blanc' deliberately echoed Coleridge's 'Hymn before Sunrise in the Vale of Chamonix' and knowingly engaged with its themes and symbols, Yeats borrowed the use of contrasts (good vs evil, young vs old, art vs nature, body vs soul) from Blake; Byron borrowed from Wordsworth; Coleridge borrowed from Amos Cottle's translation of Edda of Saemund' (1797) the description of moonbeam "like April hoar-frost spread" and used it in his 'The Rime of The Ancient Mariner', and, in another position, he converted several words from Dante's 'inferno' (1308) into the stanza (lines 445-51) of that poem. Even Burwick and McKusick (xxxiv) admit that Anster's poem 'The Times' imitated from Coleridge's 'France: An Ode and Reflections on Having left a place of Retirement'. This is especially true for the earlier translations of the First Part of Faustus as well. In my investigation, I found so many instances of

${ }^{31}$ Tilar J. Mazzeo (2006). Plagiarism and Literary Property in the Romantic Period.University of Pennsylvania Press. 
lexical borrowings between various passages from the play in the anonymous 1821 Faustus and two other translations by John Anster ${ }^{32}$ and Leveson-Gower ${ }^{33}$ where the translators used the same words (content and function words) though Gower borrowed less frequently than the 1821 anonymous translator. For example ${ }^{34}$ :

- Lines 354-364:

Faustus 1820

\section{Alas! I have explored}

Philosophy, and law, and medicine,

And over deep divinity have pored,

Studying with ardent and laborious zeal

And here I am at last, a very fool,

With useless learning cursed,

No wiser than at first!

They call me doctor-

And I lead These ten years past my

pupils' creed,

Anonymous Faustus 1821

Now I have toil'd thro' all; philosophy,

Law, physic, and theology: alas

All, all I have explor'd

; and here I am A weak blind fool at

last : in wisdom risen

No higher than before:

Master and Doctor

They style me now; and I for ten long years

Have led my pupils up and down, thro' paths

Involv'd and intricate, only to find

Faustus 1823

WITH medicine and philosophy have

no more to do;

And all thy maze, theology,

At length have waded through

And stand a scientific fool,

\footnotetext{
${ }^{32}$ John Anster (trans.) 'The Faustus of Goethe', Blackwood's Edinburgh Magazine, vii, 1820.

${ }^{33}$ Leveson-Gower (trans.) Faust: A Drama By Goethe, 1823.

${ }^{34}$ This list is by no means exhaustive but it shows the issue of borrowing that is available in the translations of Faustus. It also shows that the anonymous 1821 borrowed from the 1820 version, where examples could be easily extended if I had time and patience.
} 
As wise as when I went to school.

'Tis true, with years of science ten,

A teacher of my fellow men,

Above, below, and round about,

- Lines 428-435:

Faustus 1820

Ha! What new life divine, intense,

Floods in a moment

Every sense;

I feel the dawn of youth again,

Visiting each glowing, vein!

Was it a God, who wrote

this sign? The tumults of my soul

are stilled,

My withered heart with

rapture filled!

Anonymous Faustus 1821

Ha! What delight does in a moment fill

My senses at this sight! I feel at once

The renovated streams of life and pleasure

Bubble thro' every vein. Was it a god

Who wrote this sign?its tills my soul's wild

warfare; Fills my lost heart with joy, while some

strange impulse

Faustus 1823

Spirits, ye that hover near,

Speak and answer,

if ye hear!Ha! what rapture

from the sight

Fills my veins with

wild delight!

Sure some God the sign has traced.

In these features,plain and true,

Nature's secrets greet my view

Given that the majority of the words and phrases Professor Burwick spotted can be found in many places throughout the Romantic-era writings, I doubt that they are Coleridgean or stylistically specific to Coleridge and, therefore, they are insufficient to 
connect him with the Faustus translation.

Perhaps because the documentary record and the internal or linguistic evidence are not complete enough to give a definitive answer, Professor Mckusick brought computational stylometry of the Faustus translation in direct comparison with two plays by Coleridge and two plays translated by him and five other translations of the play, by Germaine de Staël, George Soane, Daniel Boileau, John Anster and Lord Francis Leveson-Gower. He used word length distribution (2-8 letter-words) and the frequencies of function words and applied the chi-squared test to determine whether the differences in word frequencies for the anonymous 1821 Faustus and various translations of the play and Coleridge's plays were statistically significant or not. Professor Mckusick's analysis supported the case for Coleridge's authorship of the 1821 Faustus, but only weakly. Word-length distribution is an intuitively attractive linguistic style marker, but one whose effectiveness in characterizing authorial style and in distinguishing one author from another is at the very least not demonstrated, and there are indications that it is ineffective. Professor McKusick explicitly recognized this in which he only went so far as to say that the "general similarity in vocabulary, as reflected in word-length distribution, between Remorse and the 1821 Faustus" is "suggestive". The function word distribution is a much better linguistic style marker, but Professor Mckusick again claims only that it does not "prove" Coleridgean authorship, but is only "consistent with" it. Professor McKusick appears to realize that the real problem lies not in the selection of linguistic style markers, fundamental as this is, but with logic. A statistically significant difference between two texts relative to some given criterion tells one only that the texts are different, not that they are by different authors and a statistically non-significant difference that the texts are similar in terms of that criterion, but not that they are by the same author. Professor McKusick's results can only serve to support Coleridgean authorship in this instance. He is thus right in claiming only that his results are consistent with the hypothesis of Coleridgean authorship, but his further claim that they "indicate a strong likelihood" of it is unjustified.

Overall, it is evident that the claim of Coleridge authorship of the 1821 Faustus translation is not supported with conclusive documentary, linguistic and statistical evidence. On that basis, the case for Coleridge has not been made ${ }^{35}$.

\footnotetext{
${ }^{35}$ In 2015, I set out to test the result of the statistical section (pp. 312-30) of Professor McKusick. The corpus consisted of 363 texts by Coleridge, the anonymous 1821 Faustus, and six other translations of the play by Staël (1813), Shelley (1815); Anster (1820); Boileau (1820); Gower (1823), and Soane (1821-1825). I used 80 function words, applied different multivariate analytical methods, and I found that Coleridge's works are mathematically quite different from the 1821 Faustus translation. The complete study is available fromhttps://core.ac.uk/download/pdf/15377990.
} 


\section{The Author}

\section{Refat Aljumily}

Email: Refat.A.70@outlook.com

\section{The Article}

Date sent: 03/02/2021

Date revised: 25/03/2021

Date Accepted: 26/03/2021 